\title{
Optimal Public Policy with Endogenous Mortality
}

\author{
Rangan Gupta* \\ and \\ Emmanuel Ziramba ${ }^{\dagger}$
}

August 21, 2008

\begin{abstract}
Using a monetary pure-exchange overlapping generations model, where the probability of survival of the young agents depends upon share of government expenditure on health, education and infrastructure, we analyze the welfare-maximizing policy mix between explicit and implicit taxation. We show that increases in the survival probability lead to an increase in the reliance on seigniorage as a welfare maximizing outcome. However, for our results to hold, the seigniorage tax base must be large enough for the benevolent planner to use the inflation tax.
\end{abstract}

Journal of Economic Literature Classification: H2; H51; I1; I18

Keywords: Monetary Pure Exchange Overlapping Generations Model; Probability of Survival; Welfare Maximizing Policy Mix.

\footnotetext{
*To whom correspondence should be addressed. Contact Details: Associate Professor, University of Pretoria, Department of Economics, Pretoria, 0002, South Africa, Email: Rangan.Gupta@up.ac.za. Phone: +27 12420 3460, Fax: +27 123625207.

${ }^{\dagger}$ Contact Details: Senior Lecturer, University of South Africa, Department of Economics, P.O. Box 392, Pretoria, 0003, South Africa, Email: zirame@unisa.ac.za. Phone: +27 124294486.
} 


\section{Introduction}

Using a pure-exchange overlapping generations model, where the probability of survival of the agents depends upon share of government expenditure on health, education and infrastructure, we analyze optimal (welfaremaximizing) policy mix between explicit and implicit taxation. In other words, we investigate how the optimal revenue mix evolves as a benevolent social planner tends to spend greater fraction of its resources into affecting the probability of survival.

Though recent studies, such as Chakraborty (2004), Hashimoto and Tabata (2005), Bunzel and Qiao (2005), Agénor (2006) and Aisa and Pueyo (2006) have endogenized mortality rate ${ }^{1}$ in general equilibrium models by making it a function of the government expenditure on either health only or health, education and infrastructure, ${ }^{2}$ none of the studies, ${ }^{3}$ barring Agénor (2006), to some extent, have discussed the role of policies in financing such purposeful public expenditures. But, in his paper, Agénor (2006), proposes a theory of long-run development based on public infrastructure. Besides investing in infrastructure, the government, in this model, is assumed to spend on health services, which, in turn, is allowed to raise the productivity of labor and lower the rate of time preference. Moreover, infrastructure is designed to affect the production of both commodities and health services. As a result of network effects, the degree of efficiency of infrastructure is nonlinearly related to the stock of public capital itself, and this, in turn, is shown to possibly lead to multiplicity of equilibrium growth paths. The author indicates that an increase in the share of spending on infrastructure, financed by a cut in unproductive expenditure or foreign grants, may facilitate the shift from a low growth equilibrium to a high growth steady state, provided that governance is adequate enough to ensure a sufficient degree of efficiency in productive public investment.

We however, unlike Agénor (2006), are more interested in studying the change in the distributional

\footnotetext{
${ }^{1}$ A different set of studies, namely, Blackburn and Cipriani (2002), Kalemli-Ozcan (2002), and Ehrlich and Kim (2005), endogenize the mortality rate by assuming instead that the survival probability of individuals depends on either per capita income or consumption.

${ }^{2}$ See also Agénor (2005) and Agénor and Neanidis (2006) for recent studies that that have allowed for the role of health expenditures in the production process in a general equilibrium set up.

${ }^{3}$ Most of these studies have mainly concentrated on steady-state and transitional dynamics of capital accumulation and growth in the endogenous mortality, affected by public expenditure on health.
} 
structure of the revenue as the government spends greater fraction of its resources on health, education, and infrastructure, and in the process affects the probability of survival. We assume that the government finances its expenditure through direct income taxation and seigniorage, as is generally the case in developing economies, given the poorly developed public debt market. ${ }^{4}$ Though, we must confess that our framework, being a pure-exchange monetary ${ }^{5}$ overlapping generations model, is much simpler than the elaborate endogenous growth model used by Agénor (2006). Nevertheless, our framework is suitable enough to study the change in the welfare maximizing policy mix as the probability of survival increases with the government spending greater fraction of its resources in health, education and welfare. An immediate extension of this study would obviously be to check for the robustness of the obtained results based on an endogenous growth framework comparable to that of Agénor (2006). But, to the best of our knowledge, this is the first attempt to study policy mix in the presence of endogenously determined survival probability. The remainder of the paper is organized as follows: Section 2 outlines the economic environment; Section 3 and 4 respectively, are devoted to defining the competitive equilibrium and analyzing the welfare-maximizing policy mix following an increase in the share of government expenditure on health, education and infrastructure expenditures in total public outlays. Finally, Section 5 concludes.

\section{Economic Environment}

The economy is populated by three types of agents, namely, consumers, banks (financial intermediaries), and an infinitely-lived government. Time is discrete and there is an infinite sequence of agents indexed by $t=1,2,3, \ldots \ldots$. Agents live for no more than two periods. Each two-period lived overlapping generations consumer/household has preferences defined over a consumption good. The consumer is endowed with $y$ units of the consumption good when young. The agent divides the net of tax endowment, $\left(1-\tau_{t}\right) y$ between consumption, $c_{t}$ and savings, $d_{t}$. The savings are deposited into a bank, operating in a perfectly competitive

\footnotetext{
${ }^{4}$ See Holman and Neanidis (2006) for further details.

${ }^{5}$ We follow Drazen (1989), Bacchetta and Caminal (1992), Haslag and Hein (1995), Espinosa and Yip (1996), Haslag (1998), Haslag and Koo (1999), Bhattacharya and Haslag (2001), Gupta (2005, 2006, 2008a, b) and Gupta and Ziramba (2008a,b,c,d,e) amongst others in introducing money through cash-reserve deposit ratio that the banks in the economy needs to maintain.
} 
market. ${ }^{6}$ When old, the consumer consumes out of the return on one's young age savings. Thus, at time $t$, there are two coexisting generations of young and old. Young agents of unit measure are born at each period of time. However, they only survive into the next period with probability $\phi_{t}$, with the survival probability depending upon their health capital. We assume that the health capital is determined by the fraction of the government spending that is devoted to health, education and infrastructure investment per young person. The young agent born at time point $t$ gives birth to a child at the end of period $t$, before realizing the mortality shock. The new individual becomes economically active at the beginning of the next period $(t+1)$, but is not assumed to inherit the parent's health stock.

Formally, the agent's problem born in period $t$ is as follows:

$$
U\left(c_{t}, c_{t+1}\right)=\log c_{t}+\phi_{t} \log c_{t+1}
$$

subject to:

$$
\begin{aligned}
& c_{t}+d_{t}=\left(1-\tau_{t}\right) p_{t} y \\
& c_{t+1}=\frac{\left(1+i_{d t+1}\right)}{\phi_{t}} d_{t}
\end{aligned}
$$

where $U($.$) is the utility function, with the standard assumption of positive and diminishing marginal utility;$ $\phi$ is the probability of survival into the next period; $c_{t}\left(c_{t+1}\right)$ are the respective young and old age consumption of consumption levels; $d_{t}$ are the real deposits held in period $t ; \tau_{t}$ is the tax rate at period $t ; p_{t}$, is the price of the consumption good at period $t ; i_{d t+1}$ is the nominal interest rate on bank deposits. Each unit of the consumption good placed into deposits at date $t$ yields $\left(1+r_{d t+1}\right)=\frac{\left(1+i_{d t+1}\right)}{1+\pi_{t+1}}$ with $\left(1+\pi_{t+1}\right)=\frac{p_{t+1}}{p_{t}}$ as the gross inflation rate. Note $\phi$, the probability of survival, is defined as a non-decreasing concave function

$$
\phi_{t}=\frac{\beta \psi\left(\frac{g_{t}}{y}\right)}{1+\beta \psi\left(\frac{g_{t}}{y}\right)}
$$

satisfying $\phi(0)=0$ and $\lim _{\frac{g_{t}}{y} \rightarrow 1} \phi\left(\frac{g_{t}}{y}\right)=\frac{\beta}{1+\beta}<1 ; \beta>0$ is a positive scalar; and, $0<\psi<1$ denotes the fraction of the government expenditure devoted to building up the per capita health capital.

\footnotetext{
${ }^{6}$ If the banking sector was not perfect then, a higher survival rate would increase the rate of returns on savings and encourage more deposits. Note we could have also assumed the households to self-insure against mortality risks via inter-family transfers, in the absence of a banking sector.
} 
Banks receive the deposits $d_{t}$ and are subjected to a standard cash reserve requirement which constraints the banks to hold at least $\gamma_{t}$ of each unit of the good deposited, in the form of money. In equilibrium, with money being return-dominated, banks will hold exactly a fraction $\gamma_{t}$ in fiat money. Let $M_{t}$ denote the nominal money balances per young person. Then, $M_{t}=\gamma_{t} p_{t} d_{t}$ holds. The rest is invested into riskless assets. An investment of one unit of consumption good in period $t$ produces $1+x$ units of consumption good in period $t+1$. Consumers do not have direct access to this riskless investment, and, hence, require the banks to perform a pooling function on their behalf. ${ }^{7}$ Thus, the only form of savings for the consumers is through the deposits with the financial intermediaries. Because fiat money does not pay any interest rate, the gross real return on money between $t$ and $t+1$ is $\frac{1}{1+\pi_{t+1}}$. Throughout the analysis we restrict our attention to equilibria where money is return dominated, or $1+x>\left(1 /\left(1+\pi_{t+1}\right)\right)$. Alternatively, $\left(1+i_{l t+1}\right)>1$, where $i_{l t}$ is the nominal return on bank investment.

The banking sector is assumed to be perfectly competitive and banks have access to a costless intermediation technology. Profit maximization on behalf of the banks causes the gross real return on deposits to be a weighted average of the returns from the investment and money, with the weights being defined the reserve-deposit ratio. Formally,

$$
1+r_{d t+1}=\left(1-\gamma_{t+1}\right)(1+x)+\gamma_{t+1} \frac{1}{1+\pi_{t+1}}
$$

must hold.

The government is assumed to be infinitely-lived. It purchases $g_{t}$ units of the consumption good. $\psi$ fraction of the public good which is assumed to be useful in the sense that they indicate the fraction of total government expenditure devoted to building up the health capital of the young individual through investments in health, education and infrastructure. The total government expenditure is financed through income taxation, and seigniorage. In real per-capita terms the government budget constraint can be written as follows:

$$
g_{t}=\tau_{t} y+\frac{M_{t}-M_{t-1}}{p_{t}}
$$

\footnotetext{
${ }^{7}$ Implicitly, we are assuming that the investment into the riskless assets needs to be in bulk, and, hence, cannot be accessed by the young agents on their own.
} 
with $M_{t}=\left(1+\theta_{t}\right) M_{t-1}$ and where $\theta$ is the net money growth rate. Note, the consolidated government coordinates the activities of the treasury and the central bank, both of which are "equally subservient to the government". The benevolent government maximizes the steady state level of welfare for all future generations, obtained by substituting the equilibrium decision rules into the agents' utility function to determine the optimal reliance on direct taxation and seigniorage as the value of $\psi$ increases.

\section{Equilibrium}

A competitive equilibrium for this economy is a sequence of prices $\left\{p_{t}, i_{d t}, i_{l t}\right\}_{t=0}^{\infty}$, allocations $\left\{c_{t}, c_{t+1}\right\}_{t=0}^{\infty}$, stocks of financial assets $\left\{m_{t}=\frac{M_{t}}{p_{t}}, d_{t}\right\}_{t=0}^{\infty}$, and policy variables $\left\{\gamma_{t}, \mu_{t}, \tau_{t}, g_{t}\right\}_{t=0}^{\infty}$ such that:

- The consumer maximizes utility given by (1) subject to (2) and (3);

- Banks maximize profits, taking $i_{l t}, i_{d t}$, and $\gamma_{t}$ as given and such that (5) holds;

- The money market equilibrium conditions: $m_{t}=\gamma_{t} d_{t}$ is satisfied for all $t \geqslant 0$;

- The goods market equilibrium condition require: $c_{t}+c_{t+1}+g_{t}=y$ is satisfied for all $t \geqslant 0$;

- The government budget is balanced on a period-by-period basis;

- $d_{t}, i_{d t}, i_{L t}$, and $p_{t}$ must be positive at all dates and $1+x_{t+1}>\left(1 /\left(1+\pi_{t+1}\right)\right)$.

\section{Optimal Public Policy}

In this section, we analyze how the optimal policy mix between direct taxation and seigniorage would vary as the government spends greater fraction of its resources in building the health capital of the young agents. In other words, we want to study how government raises its revenue as the value of $\psi$ increases given the size of the government $\frac{g_{t}}{y}=z_{t}$. For the sake of tractability we will assume that the government follows time-invariant decision rules, i.e., $\tau_{t}=\tau, \gamma_{t}=\gamma, \theta_{t}=\theta$ and finally, $z_{t}=z$. We will also assume that $\tau y=$

$\delta \times g_{t}$ and, hence, $\frac{M_{t}-M_{t-1}}{p_{t}}=(1-\delta) \times g_{t}$, with $0 \leq \delta(1-\delta) \leq 1$ indicating the share of taxes (seigniorage) in total government expenditures. 
Given this, we investigate the behavior of a benevolent government or social planner who maximizes the utility of all consumers, evaluated at the steady state, by choosing $\delta$ following increases in the value of of $\psi$. Specifically, the problem for the social planner, with the discount rate of $\phi$, is captured by: $W=$ $\sum_{i=0}^{\infty} \phi^{i} U\left(c_{t+i}, c_{t+1+i}\right)$, subject to $0 \leq \delta \leq 1$. Formally, we have the following problem:

$$
\max _{0<\delta<1} W=\frac{1}{1-\phi} \log c_{t}^{*}+\frac{\phi}{1+\phi} \log c_{t+1}^{*}
$$

where $c_{t}^{*}=\frac{1}{1+\phi}(1-\tau) y ; c_{t+1}^{*}=\frac{1}{1+\phi}\left[(1+x)(1-\gamma)+\frac{\gamma}{1+\theta}\right](1-\tau) y ; d_{t}^{*}=\frac{\phi}{1+\phi}(1-\tau) y ; \phi=\frac{\beta \psi z}{1+\beta \psi z} ; \tau=\delta z$; and $\theta=\left(\frac{\beta \gamma(-1+z \delta) \psi}{1+2 z \beta \psi-\beta \gamma \psi+\delta(-1+z \beta(-2+\gamma) \psi)}-1\right)$ using the government budget constraint and the fact that the money market equilibrium holds.

The problem of the social planner is a cubic function in $\delta$, and, hence, yields analytical solutions that are difficult to analyze, given the complexity of the two roots. Numerical analysis of the problem, in turn, requires values for the structural parameters of the model. For our experiments below, we use the following set of values based on a combination of figures from previous studies and those that we calibrate. ${ }^{8}$

A first set of parameter values is given by numbers usually found in the literature. The following parameter values were chosen initially and the specific source is mentioned in the parentheses given aside, except for the standard ones. These are:

- $\gamma$ : the annual reserve-deposit ratio was fixed at 0.25 (Haslag and Young (1998));

- $\tau$ : tax rate was set to 0.20 or 20 percent (Chari et al. (1995));

- $\pi$ : the annual rate of inflation was fixed at 10 percent, and, hence, the gross rate of inflation was $1+\pi=1.10(\operatorname{Basu}(2001))$

- $x$ : net real return on banks' investment in the riskless asset. It was set at a value of 2 percent (Bhattacharya and Haslag (2001));

- $\phi$ : The survival probability was fixed at 0.80 (Chakraborty (2004)).

A second set of parameters are are calibrated from the steady-state equations of the model to make them hold exactly: These parameters are:

\footnotetext{
${ }^{8}$ The qualitative results of the model are, however, unchanged to alternative choices of parameter values.
} 
- $\mu$ : the annual rate of money supply was fixed at 10 percent, and, hence, the gross money supply rate was $1+\mu=1.10=1+\pi$, given the money market equilibrium;

- $\frac{g}{y}$ : the ratio of government expenditure to income. Given the values for $\tau, \gamma, \theta$ and $\phi$, this was calibrated to a value of 20.81 percent from the government budget constraint;

- $\psi$ : the share of health, education and infrastructure in total government expenditure, was obtained using the fact that the average public expenditure share on health, education and infrastructure for over eighty lower income, lower middle income and upper middle income developing countries amounted to 7.10 percent of the GDP (Estache et al. (2007)). Using the calibrated value of the total government outlays to GDP, this yielded a value of 0.3412 for $\psi$.

- $\beta$ : the scalar in the survival probability function was calibrated to 56.34 so that it matched a value of $\phi=0.80$, given $\psi=0.3412$.

Note maximization of the welfare function, $W$, with respect to $\delta$ yielded two roots for $\delta$ as a function of the other parameters of the model. Once the calibrated values of the structural parameters were replaced, the minimum values of $\gamma$ required to ensure that the roots of $\delta$ was between 0 and 1 were, respectively, 0.62 and $0.17 .^{9}$ Because the value of 0.62 for $\gamma$ was higher than 0.25 , the value used in the calibration, we decided to discard the root that yielded this value of $\gamma \cdot{ }^{10}$ Now, assuming a value of $\gamma=0.25$, Figure 1 plots the relationship between $\delta$ and $\psi$, with the value of $\psi$ being increased from 0.3412 to 1.0. ${ }^{11}$

As can be seen from Figure 1, increases in survival probability as the share of health, education and infrastructure increases in the total government expenditure, causes $\delta$ to fall. In other words, the reliance of the benevolent government on seigniorage tends to increase. Intuitively speaking the result makes perfect sense. As the probability of survival increases, ceteris paribus, both young- and old-age consumptions tend

\footnotetext{
${ }^{9}$ The welfare-maximizing solutions for the optimal $\delta$ yielded a cubic equation in $\gamma$. For our calibration the two other roots for each of the solutions of $\delta$ were greater than one, and hence, were ignored.

${ }^{10}$ See Bhattacharya and Haslag (2001) for further details regarding the procedure adopted.

${ }^{11}$ The relationship between $\psi$ and the cut off $\gamma$ required to ensure a positive $\delta$, was found to be negative, hence, our choice of $\gamma=0.25$ was maintained for higher values of $\psi$ used in the experiment. Interestingly, if the binding reserve requirements are a metric for financial repression (Gupta, 2005, 2006, 2008a,b and Gupta and Ziramba, 2008a,b,c,d,e), our result indicates that financial repression should be negatively related with the probability of survival.
} 
to fall, while, saving, understandably increases, given the fixed endowment. In such a scenario, it is then optimal for the government to reduce the tax rate to boost young age consumption directly and old age consumption through savings. However, with the reliance on tax rate going down and a fixed amount of government expenditure to be financed, the government has to resort to seigniorage. This, in turn, results in higher money growth rate, given the binding reserve requirements, and, hence, taxes the old indirectly.

Recall, that taxes on the old are not available, hence, seigniorage serves as the viable alternative for a tax on the old. The fact that the increased use of the inflation tax is an optimal move as the survival probability increases, is easily understood when one realizes that the weight $\left(\frac{1}{1-\phi}\right)$ on young age consumption in the welfare function is greater than the weight $\left(\frac{\phi}{1-\phi}\right)$ on the old-age consumption, even though both the weights tends to increase at the same rate of $\frac{1}{(1-\phi)^{2}}$ as $\phi$ increases. However, it must be noted, that the mere fact that use of seigniorage indirectly taxes the old is not a sufficient justification for its higher utilization as a part of welfare maximizing outcome following increase in the survival rate. The reserve requirement has to be large enough to warrant the use of seigniorage. If the reserve requirement is below the threshold level, the gap between returns to the riskless asset $(x)$ and deposits $\left(r_{d}\right.$, is too small, which, in turn, implies that the old cannot be taxed as required to satisfy the governments budget constraint. ${ }^{12}$ Alternatively speaking, our results only hold, when the seigniorage tax base is large enough for the benevolent planner to use the inflation tax..$^{13}$

\section{Conclusion}

In this paper, using a monetary pure-exchange overlapping generations model, where the probability of survival into the next period depends on the share of health, education and infrastructure expenditures in total public outlays, we analyze the welfare-maximizing policy mix between explicit and implicit taxation. In other words, we investigate how the optimal revenue mix evolves as a benevolent social planner tends to spend greater fraction of its resources into affecting the probability of survival.

\footnotetext{
${ }^{12}$ Note, for every unit of young age savings, the agent loses $\left(x-r_{d}\right)$ units of income when old because of the binding reserve requirement. It is in this sense that it is ultimately the old agents who are effectively getting taxed, if seigniorage is employed. ${ }^{13}$ See Bhattacharya and Haslag (2001) for further details.
} 
When numerically analyzed for a world economy, the following basic conclusions could be drawn: (i) Increases in the survival probability leads to an increase in the reliance on seigniorage as an welfare maximizing outcome; (ii) Hence, given a binding reserve requirement, increases in the survival rate is found to optimally cause higher inflation via the increase in the money growth rate causing the rise in the seigniorage ${ }^{14}$; (iii) However, for our results to hold, the seigniorage tax base, determined by the size of the cash reserve requirements, must be larger than a threshold value for the benevolent planner to use the inflation tax. As suggested at the onset, given the simplified nature of our endowment economy model, it would be worthwhile to check for the robustness of our results by moving to an endogenous growth framework similar to that of Hashimoto and Tabata (2005) and Agènor (2006).

\footnotetext{
${ }^{14}$ Note the rise in seigniorage is not only due to a rise in the money growth rate, but also due to a fall in the tax rate which causes the size of the deposits, and, hence, the seigniorage base to increase, given the threshold level of reserve requirements.
} 


\section{References}

[1] Agènor, P-R. (2006). A Theory of Infrastructure-led Development. The University of Manchester Discussion Paper series Number 083.

[2] Agènor, P-R. (2005). Health and Infrastructure in Models of Endogenous Growth. The University of Manchester Discussion Paper series Number 062.

[3] Agènor, P-R. and Neanidis, K. C. (2006). The Allocation of Public Expenditure and Economic Growth. The University of Manchester Discussion Paper Series Number 069.

[4] Aisa, R. and Pueyo, F. (2006). "Government Health Spending and Growth in a Model of Endogenous Longevity", Economics Letters, Vol. 90, pp. 249-253.

[5] Bacchetta, P., and Caminal, R. (1992). "Optimal Seigniorage and Financial Liberalization", Journal of International Money and Finance, Vol. 11, No 5, pp. 518-538.

[6] Barro, R.J. (1990). "Government Spending in a Simple Model of Endogenous Growth", Journal of Political Economy 98, No (5, Part 2) : pp. s103- s125.

[7] Barro, R.J. and Sala-i-Martin, X. (1992). "Public Finance in Models of Economic Growth", Review of Economic Studies, Vol. 59, pp. 645- 661.

[8] Basu, P. (2001). "Reserve Ratio, Seigniorage and Growth", Journal of Macroeconomics, Vol. 23, No 3, pp. 397-416.

[9] Bhattacharya, J., and Haslag, J. H. (2001). "On the Use of Inflation Tax When Non-distortionary Taxes are Available", Review of Dynamics, Vol. 4, No 4, pp. 823-841.

[10] Bunzel, H., and Qiao, X. (2005). "Endogenous Lifetime and Economic Growth Revisited", Economics Bulletin, Vol. 8, pp. 1-8.

[11] Caprio, G., Honohan, P., Stiglitz, J. E. (2001). Financial Liberalization: How far, How Fast? Cambridge University Press, Cambridge, UK. 
[12] Chakraborty, S. (2004). "Endogenous Lifetime and Economic Growth", Journal of Economic Theory, Vol. 116, pp. 119-137.

[13] Chari, V.V., R. E., and Manuelli, L. E. Jones (1995). "The Growth Effects of Monetary Policy." Quarterly Review, Federal Reserve Bank of Minneapolis, Vol. 19, No 4, pp. 18-32.

[14] Drazen, A. (1989). Monetary Policy, Seigniorage, and Capital Controls in an Open Economy. In An European Central Bank? (M. de Cecco and A. Giovannini, eds.) Cambridge: Cambridge University Press, pp. 13-52.

[15] Ehrlich, I. and Kim, J. (2005). "Endogenous Fertility, Mortality and Economic Erowth: Can a Malthusian Framework Account For the Conflicting Historical Trends in Population?", Journal of Asian Economics, Vol. 16, No 5, pp. 789-806.

[16] Espinosa, M., and Yip, C. K. (1996). An endogenous growth model of money, banking, and financial repression. Working Paper No. 96-4, Federal Reserve Bank of Atlanta.

[17] Estache, A., Gonzalez, M., and Trujillo, L. (2007). Government Expenditures on Education, Health, and Infrastructure: A Naive Look at Levels, Outcomes, and Efficiency. World Bank Policy Research Working paper 4219.

[18] Gupta, R. (2005). "Costly State Monitoring and Reserve Requirements", Annals of Economics and Finance, Vol.6, No. 2 pp. 263-288.

[19] Gupta, R. (2006). "Asymmetric Information, Tax Evasion and Alternative Instruments of Government Revenue", The ICFAI Journal of Monetary Economics, Vol 4, No.1, pp. 75-89.

[20] Gupta, R. (2008a). "Tax Evasion and Financial Repression", Journal of Economics and Business, Forthcoming.

[21] Gupta, R. (2008b). Currency Substitution and Financial Repression. ERSA Working Paper 70. Department of Economics, University of Cape Town. 
[22] Gupta, R. and Ziramba, E. (2008a). Tax Evasion and Financial Repression: A Reconsideration Using Endogenous Growth Models. ERSA Working Paper 81. Department of Economics, University of Cape Town.

[23] Gupta, R. and Ziramba, E. (2008b). Openness, Bureaucratic Corruption and Public Policy in an Endogenous Growth Model. Working Paper 200817, Department of Economics, University of Pretoria.

[24] Gupta, R. and Ziramba, E. (2008c). Costly Tax Enforcement and Financial Repression. Working Paper 200818, Department of Economics, University of Pretoria.

[25] Gupta, R. and Ziramba, E. (2008d). Misalignment in the Growth-Maximizing Policies Under Alternative Assumptions of Tax Evasion. Working Paper 200819, Department of Economics, University of Pretoria.

[26] Gupta, R. and Ziramba, E. (2008e). Costly Tax Enforcement and Financial Repression: A Reconsideration using an Endogenous Growth Model. Working Paper 200820, Department of Economics, University of Pretoria.

[27] Hashimoto, K. and Tabata, K. (2005). "Health Infrastructure, Demographic Transition and Growth", Review of Development Economics, Vol. 9, No. 4, pp. 549-562.

[28] Haslag, J. H. (1998). "Monetary Policy, Banking and Growth", Economic Inquiry, Vol. 36, No. 3, pp. $489-500$.

[29] Haslag, J. H., and Hein, S. E. (1995). "Does it Matter How Monetary Policy is Implemented?”, Journal of Monetary Economics, Vol. 35, No. 2, pp. 359-386.

[30] Haslag, J. H., and Koo, J. (1999). Financial Repression, Financial Development and Economic Growth. Working Paper No. 99-02, Federal Reserve Bank of Dallas.

[31] Haslag, J. H., and Young, E. R. (Jul. 1998). "Money Creation, Reserve Requirements, and Seigniorage", Review of Economic Dynamics, Vol. 1, No. 3, pp. 677-698. 
[32] Kalemli-Ozcram, S. (2002). "Does Mortality Decline Promote Economic Growth?", Journal of Economic Growth, Vol. 7, pp. 411-429. 
Figure 1: Relationship between the Share of Taxes in Government Revenue $(\delta)$ with the Share of Public Expenditure on Health, Education and Infrastructure

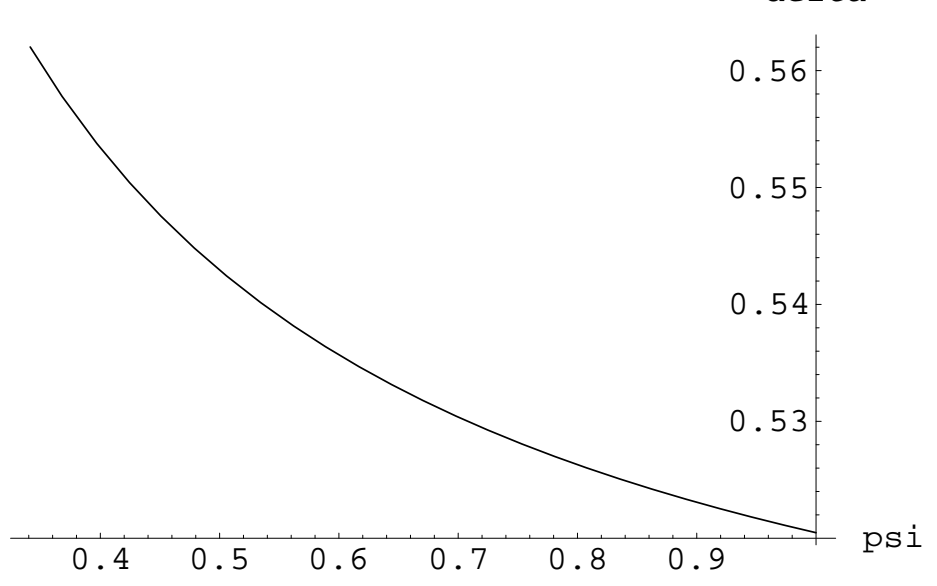

